\title{
Physicochemical Characteristics of Protein-Enriched Restructured Beef Steaks with Phosphates, Transglutaminase, and Elasticised Package Forming
}

\author{
Sephora Baugreet, ${ }^{1,2}$ Joseph P. Kerry, ${ }^{2}$ Paul Allen, ${ }^{1}$ Eimear Gallagher, ${ }^{1}$ \\ and Ruth M. Hamill (iD) \\ ${ }^{1}$ Food Quality and Sensory Science Department, Teagasc Food Research Centre, Ashtown, Dublin 15, Ireland \\ ${ }^{2}$ Food Packaging Group, School of Food and Nutritional Sciences, Food Science Building, University College Cork, Cork, Ireland \\ Correspondence should be addressed to Ruth M. Hamill; ruth.hamill@teagasc.ie
}

Received 5 January 2018; Revised 3 April 2018; Accepted 17 April 2018; Published 14 May 2018

Academic Editor: José A. Beltrán

Copyright (c) 2018 Sephora Baugreet et al. This is an open access article distributed under the Creative Commons Attribution License, which permits unrestricted use, distribution, and reproduction in any medium, provided the original work is properly cited.

\begin{abstract}
Restructured beef steaks were formulated by adding protein-rich ingredients (pea protein isolate (PPI), rice protein (RP), and lentil flour (LF) (at 4 and 8\%)), phosphate (0.2\%), and two binding agents: $1 \%$ (TG) and $0.15 \%$ (TS). The effects of their addition on the physicochemical properties of the beef steaks were investigated. Protein content of the RP8TG sample was significantly higher than that of the control in both the raw and cooked state. Raw LF4TS exhibited greater $(P<0.01) a^{*}$ values than the control; however, after the cooking process, $L^{*}, a^{*}$, and $b^{*}$ values were similar for all treatments. Textural assessment showed that elevating protein level increased $(P<0.001)$ hardness, chewiness, cohesiveness, and gumminess in cooked restructured steaks. LF addition reduced all textural values assessed, indicating a strong plant protein effect on texture modification. The commercial binder produced a better bind in combination with protein ingredients. This facilitated the production of uniformed restructured beef steaks from low-value beef muscles with acceptable quality parameters using a novel process technology.
\end{abstract}

\section{Introduction}

Animal-based foods have been a part of the human diet for many centuries, contributing significantly to total protein intake. Currently, the concept of healthy eating trends, natural and "clean label" around meat consumption, represents a rapidly growing segment among consumers [1]. Currently, there is no definition for the term "clean label"; however, this term is generally implied for foods that are minimally processed, are made from wholesome ingredients, and are free from artificial ingredients and allergens. Previously, plant proteins have been used in meat systems for their functional properties rather than nutritional profile [2]. Modi et al. [3] and Serdaroğlu et al. [4] used chickpea, lentil, and soya flour as extenders and binders in processed meat products and observed a significant increase in protein content. Baugreet et al. [5] examined the technological performance of protein-enriched beef patties with pea and rice protein. Results showed that plant ingredients could offer opportunities to enhance the protein content in the diet by complementing or associating with other traditional food sources such as animal protein, for example, through incorporation into staple food vehicles.

Restructured meat products allow flexibility for novel formulations to be developed which can help meet specific nutritional goals, such as targeted protein content. The combination of restructuring technology and the PiVac technology can facilitate the development of low-cost, controlled portion size meat products from low-value cuts and trimmings [6]. The PiVac technology, a packaging system, is so far a wrapping technique, which involves placing hot-boned or muscle pieces in an elasticised casing material, thus preventing muscle toughening and producing a uniformly shaped meat product (Hans-Werner Meixner, 2018, personal communication, 26 March, confirming that descriptions are accurate) [7]. This system operates with the 
TABLE 1: Formulation of restructured beef steaks.

\begin{tabular}{|c|c|c|c|c|c|c|c|c|}
\hline Formulations & Beef $(\mathrm{g})$ & Phosphate (g) & Vits/mins (g) & Ing. (g) & TG (g) & TS (g) & Water $(\mathrm{g})$ & Total (g) \\
\hline Control & 2194.00 & 5 & 1 & - & - & - & 200 & 2500 \\
\hline PPI4TG & 2069.00 & 5 & 1 & 100 & 25 & - & 200 & 2500 \\
\hline PPI4TS & 2090.25 & 5 & 1 & 100 & - & 3.75 & 200 & 2500 \\
\hline PPI8TG & 1969.00 & 5 & 1 & 200 & 25 & - & 200 & 2500 \\
\hline PPI8TS & 2090.25 & 5 & 1 & 200 & - & 3.75 & 200 & 2500 \\
\hline RP4TG & 2069.00 & 5 & 1 & 100 & 25 & - & 200 & 2500 \\
\hline RP4TS & 2090.25 & 5 & 1 & 100 & - & 3.75 & 200 & 2500 \\
\hline RP8TG & 1969.00 & 5 & 1 & 200 & 25 & - & 200 & 2500 \\
\hline RP8TS & 2090.25 & 5 & 1 & 200 & - & 3.75 & 200 & 2500 \\
\hline LF4TG & 2069.00 & 5 & 1 & 100 & 25 & - & 200 & 2500 \\
\hline LF4TS & 2090.25 & 5 & 1 & 100 & - & 3.75 & 200 & 2500 \\
\hline LF8TG & 1969.00 & 5 & 1 & 200 & 25 & - & 200 & 2500 \\
\hline LF8TS & 2090.25 & 5 & 1 & 200 & - & 3.75 & 200 & 2500 \\
\hline
\end{tabular}

Ing: ingredients; vits/mins; vitamins/minerals; control (CP), pea protein isolate (PPI), rice protein (RP), and lentil flour (LF) (at 4 and $8 \%$ ); binding agents: Activa $^{\mathrm{EB}}$ (TG), and Transgluseen-M (TS).

insertion of meat muscle into expandable casings to the inside walls of the packaging chamber, and upon release of the stretching/wrapping, the tube contracts to its original shape exerting pressure on the meat [8]. When the vacuum is turned off, the flexible material retracts to its original dimensions. Formulation of such products with ingredients such as plant proteins can permit further enhancement of the protein content. To achieve desired quality parameters associated with traditional restructured meat products in terms of appearance and texture, binders such as transglutaminase enzyme and phosphates may be used. A low-salt ( 1.0-1.4\% NaCI) meat product that might be beneficial for the general population can be prepared with the use of phosphates. Phosphates enhance texture, water holding capacity, emulsion stability, and shelf life [9]. On the other hand, the transglutaminase enzyme has been widely used in restructured meat products [10]. This unique enzyme has been previously used in many studies to enhance textural properties and other characteristics (cohesion, cook yield, palatability, etc.) of restructured chicken, pork, and lamb [11].

To date, relatively little work has been done to investigate the effect of interactions between transglutaminase and protein ingredients on the physicochemical and technological properties of restructured meat products [12-14]. Transglutaminase reacts differently with various protein sources and at different inclusion levels; therefore the aim of this study was to assess the interactions of different plant proteins with transglutaminase in a prototype protein-enriched restructured beef steak product. In this study, PiVac technology, in association with each of the two transglutaminase ingredients, that is, Activa ${ }^{\circledR} \mathrm{EB}$, a commercial transglutaminase with maltodextrin and sodium caseinate as additional compounds to increase cross-linking between meat and binder matrix, and Transgluseen ${ }^{\mathrm{TM}}-\mathrm{M}$, a minimally processed natural binder, was applied in the development of restructured plant protein-enriched beef products.

\section{Materials and Methods}

2.1. Experimental Design. The experiment was a $3 \times 2 \times 2$ factorial design with three ingredients (PPI, RP, LF) at two inclusion levels (4 and 8\%), with two binders Activa ${ }^{\mathrm{EB}}$ (TG) and Transgluseen-M (TS) added to each ingredient at each level, and three replications of the entire experiment were compared to a control that contained no binders or ingredients. Thirteen formulations including a control for restructured beef steaks are presented with the formulation given in Table 1.

\subsection{Raw Materials and Preparation of Restructured Beef} Steaks. Beef chucks (95\% visual lean; $45 \mathrm{~kg}$ ) were obtained from Kepak (Clonee, Ireland) and chilled overnight (1 to $\left.4^{\circ} \mathrm{C}\right)$. Beef pieces were manually trimmed off excess fat and connective tissue and then coarsely ground through a $4.28 \mathrm{~cm} \times 2.60 \mathrm{~cm}$ kidney plate in a mixer mincer (La Minerva Mixer Mincer, Bologna, Italy). Raw materials used for the preparation of the restructured steaks included potassium diphosphate (tetrapotassium pyrophosphate) (P) (AllinAll Ingredients Ltd., Dublin, Ireland), Activa ${ }^{\mathrm{EB}}$ (TG) (Ajinomoto Europe, Hamburg, Germany), Transgluseen-M (TS) (Siveele, Breda, the Netherlands), and a vitamin/mineral premix (VMP) (selenium, vitamin A, zinc, vitamin $B_{6}$, vitamin $B_{12}$, vitamin $K_{1}$, vitamin $E$, folic acid, vitamin C) (Vitablend, Wolvega, the Netherlands). Micronutrient deficiency is a challenge among older adults $[15,16]$; thus, fortification through food formulation can increase nutritional intake. Pea protein isolate (PPI) was supplied by AllinAll ingredients Ltd., Dublin, Ireland, and rice protein (RP) and lentil flour (LF) were from Healy Group, Tallaght, Dublin, Ireland.

The preparation method was as follows: ground meat (2.5 kg per batch per treatment) was mixed for $2 \mathrm{~min}$ in a mixer at a speed of $250 \mathrm{rpm} \mathrm{1/min} \mathrm{(Stephan} \mathrm{Mixer,} \mathrm{Sohne}$ GmbH \& Co., 3250 Hameln, Germany); half of the chilled water was incorporated and mixed again for 2 min; potassium diphosphate $(\mathrm{P})(0.2 \%)$ was sprinkled on and the whole mixed again for $2 \mathrm{~min}$. Binding agents were dissolved in the remaining water, added to the mixture together with the protein ingredients, and mixed for $3 \mathrm{~min}$. Finally, VMP $(20 \mathrm{mg} / 100 \mathrm{~g}$ of meat) was added and mixed for $1 \mathrm{~min}$. Mixing time was standardised at $8 \mathrm{~min}$. Each formulation was immediately placed in hand crank filler (Friedr. Dick GmbH \& Co. KG, Germany), and a plastic casing of $100 \mathrm{~mm}$ 
in diameter (Food Processing Technology, Tallaght, Ireland) was held at the end of the filler tube. Once the casing was stuffed, it was clipped at both ends using a tipper clipper (Tipper Clipper, Technopack, Glinde, Hamburg) and PiVac was applied. Meat logs were initially placed in a chill environment at $4^{\circ} \mathrm{C}$ for $16-18 \mathrm{~h}$ to provide adequate time to bind and subsequently stored in a freezer at $-20^{\circ} \mathrm{C}$ for $24 \mathrm{~h}$ prior to slicing into steaks $(1.5 \mathrm{~cm}$ thick, $\sim 107 \mathrm{~g})$ using a band saw machine (Medoc, S.A., Spain). Restructured beef steaks were individually vacuum packed (New Diamond JV006-D Vacuum Packer, Jaw Feng Machinery Ltd., Taiwan) in sous vide pouches (OPA/PP 15/75, 100-180 ${ }^{\circ} \mathrm{C}$, Versatile Packaging, Dublin, Ireland) and stored frozen at $-20^{\circ} \mathrm{C}$ until further analysis. All restructured beef steak samples were thawed at $4^{\circ} \mathrm{C}$ for 3 hours prior to cooking at $75^{\circ} \mathrm{C}$ for $12 \mathrm{~h}$ in a water bath.

2.3. Proximate Composition. Raw and cooked restructured steaks were evaluated for protein, moisture, and fat and ash contents as described by Baugreet et al. [5]. All analysis was determined in triplicate.

2.4. pH, Thawing Loss, Cooking Loss, and Dimensional Changes. The $\mathrm{pH}$ of beef trimmings and raw restructured steaks was measured using a glass probe $\mathrm{pH}$ electrode (Thermo Scientific pH meter 420A, Orion Research Inc.). Three restructured steaks from each formulation were thawed $\left(5 \mathrm{~h}, 3^{\circ} \mathrm{C}\right)$ and manually wiped with a paper towel to remove visible exudates. Thawing loss was calculated as weight loss (\%) with respect to the initial weight of frozen steaks. The thawed steaks from each formulation were cooked overnight in a water bath (Lauda M40, Delran, New Jersey, USA) $\left(12 \mathrm{~h}\right.$ at $\left.75^{\circ} \mathrm{C}\right)$ as recommended by Baldwin [17]. After $30 \mathrm{~min}$ at room temperature, steaks were manually wiped with a paper towel to remove visible exudates. Cooking loss (CL) was calculated as weight loss (\%). For dimensional changes, the thickness (six locations per steak) was measured before and after cooking.

2.5. Binding Strength. The ability of each of the sous videcooked meat pieces to adhere to one another was evaluated (bind strength), using a similar procedure to that of Field et al. [18]. Breaking force ( $\mathrm{g}$ ) and deformation $(\mathrm{mm})$ were measured using a Texture Analyser (Stable Micro Systems, Surrey, UK) equipped with a spherical probe. The probe $(\mathrm{P} / 1 \mathrm{~S})$ was pressed into the surface of the steak, perpendicular to the steak, at a constant speed of $1 \mathrm{~mm} / \mathrm{sec}$ for a distance of $15 \mathrm{~mm}$. The trigger force used was $5 \mathrm{~g}$, with $1 \mathrm{~mm} / \mathrm{sec}$ pretest speed and $1 \mathrm{~mm} / \mathrm{sec}$ posttest speed. The cell load of the texture analyser was $30 \mathrm{~kg}$, and the return distance was $35 \mathrm{~mm}$. Bind strength of the beef steaks was the product of the breaking force and deformation [19]. Bind strength was measured as the peak force $(\mathrm{g})$ required for the sphere probe equipped with a $1.9 \mathrm{~cm}$ ball, at a cross head speed of $100 \mathrm{~mm} / \mathrm{min}$ to break through a slice of meat mounted on a ring of $3.2 \mathrm{~cm}$ inner diameter [20]. Data were obtained from the average of three restructured steaks per treatment using Exponent software (Exponent 32, TA. XTPlus, Surrey, UK).

2.6. Colour Parameters. Surface colour ( $L^{*}$ (lightness), $a^{*}$ (redness), and $b^{*}$ (yellowness)) of the raw and cooked restructured beef steaks were evaluated as described by Baugreet et al. [5] using a dual beam xenon flash spectrophotometer (Hunter Associates Laboratory, Inc., Reston, VA). For raw restructured steaks, each package was opened and left to bloom for $30 \mathrm{~min}$ before measurements were recorded. For sous vide-cooked steaks, measurements were taken within $15 \mathrm{~min}$ postopening packages. The average of six readings per steak per treatment was recorded.

2.7. Textural Parameters. Texture profile analysis was performed on cooked restructured beef steaks (as prepared for cooking loss) based on a method described by [5, 21]. Nine cores of $18 \mathrm{~mm}$ cylindrical samples were taken from random locations in three cooked beef steaks per treatment.

2.8. Lipid Oxidation. Thiobarbituric acid-reactive substance (TBAR) values were determined using the method of Siu and Draper (1978) and Baugreet et al. [5]. TBAR values were measured in duplicate at days 0 and 30 of frozen storage.

2.9. Microbial Analysis. Psychrotrophic, mesophilic, Pseudomonas, lactic acid bacteria (LAB), and Enterobacteriaceae (ENT) were analysed as per the following methods: ISO 48331 [22], ISO 17401 [23], ISO 13720 [24], and ISO 15214 [25], respectively. Each measurement was performed in duplicate.

2.10. Statistical Analysis. The data were analysed by analysis of variance (ANOVA) both including and excluding the control treatments. Significant differences among treatments were assessed using Fisher's LSD test, and the level of significance was set at $P<0.05$. Data analyses were performed using GenStat Statistical Package (Release 14.1, Hertfordshire, UK).

\section{Results and Discussion}

3.1. Proximate Composition of Raw and Cooked Restructured Steaks. An overall analysis of variance (ANOVA) and means for the proximate analysis of the raw and cooked restructured beef steaks formulated with various plant proteins (PPI, RP, LF) and binders (TG, TS) at $4 \%$ and $8 \%$ are presented in Tables 2 and 3, respectively. As expected, the levels of protein in pea- and rice-treated steaks were significantly higher, in comparison with the control, especially in RP8 for both raw and cooked steaks [5]. The EC Reg. no. 1047/2012 on nutrition and health claims specifies the possibility to claim a "high in protein" in foodstuffs if at least $20 \%$ of the energy value is provided by protein [26]. Here, the developed protein restructured beef steaks provided an increased energy rate of approximately $60-75 \%$ in comparison with the required value referenced in the above-cited Regulation.

Moisture content in raw CP, PPI4TS, and LF4TS samples was similar $(P<0.01)$. This indicated that PPI4TS and LF4TS 
TABle 2: $P$ values from ANOVA for the dependent variables (excluding control) for main effects and interactions.

\begin{tabular}{|c|c|c|c|c|c|c|c|}
\hline \multirow[b]{2}{*}{ Dependent variables } & \multicolumn{7}{|c|}{ Main effects } \\
\hline & $\begin{array}{l}\text { Ing. } \\
\text { source }\end{array}$ & $\begin{array}{l}\text { Ing. } \\
\text { level }\end{array}$ & Binder & $\begin{array}{l}\text { Ing. source } \times \text { ing } \\
\text { level }\end{array}$ & Ing. source $\times$ binder & Ing. level $\times$ binder & $\begin{array}{l}\text { Ing. source } \times \text { ing } \\
\text { level } \times \text { binder }\end{array}$ \\
\hline \multicolumn{8}{|l|}{ Raw restructured steaks } \\
\hline Protein & $<0.001$ & 0.056 & 0.025 & 0.486 & 0.599 & 0.606 & 0.814 \\
\hline Moisture & 0.006 & $<0.001$ & 0.339 & 0.392 & 0.262 & 0.085 & 0.474 \\
\hline Fat & 0.012 & 0.866 & 0.771 & 0.377 & 0.611 & 0.570 & 0.840 \\
\hline Ash & 0.309 & 0.869 & 0.101 & 0.232 & 0.688 & 0.854 & 0.151 \\
\hline $\mathrm{pH}$ & $<0.001$ & 0.921 & 0.962 & 0.126 & 0.299 & $<0.001$ & 0.424 \\
\hline Thawing loss & 0.279 & 0.208 & 0.054 & 0.669 & 0.109 & 0.319 & 0.222 \\
\hline Cooking loss & 0.042 & 0.012 & 0.845 & 0.067 & 0.241 & 0.755 & 0.684 \\
\hline Diameter reduction $(\mathrm{mm})$ & 0.249 & 0.565 & 0.265 & 0.318 & 0.192 & 0.705 & 0.262 \\
\hline Thickness before & 0.169 & 0.199 & 0.053 & 0.819 & 0.916 & 0.720 & 0.886 \\
\hline Thickness shrinkage after & 0.769 & 0.010 & 0.587 & 0.993 & 0.782 & 0.779 & 0.561 \\
\hline$L^{*}$ & 0.017 & 0.087 & 0.830 & 0.612 & 0.150 & 0.304 & 0.560 \\
\hline$a^{*}$ & 0.001 & 0.719 & 0.105 & 0.102 & 0.461 & 0.644 & 0.791 \\
\hline$b^{*}$ & 0.007 & 0.015 & 0.629 & 0.646 & 0.923 & 0.749 & 0.365 \\
\hline$H$ & 0.003 & 0.034 & 0.243 & 0.353 & 0.688 & 0.952 & 0.446 \\
\hline \multicolumn{8}{|l|}{ Cooked restructured steaks } \\
\hline Protein & $<0.001$ & 0.335 & 0.009 & $<0.001$ & 0.003 & 0.018 & $<0.001$ \\
\hline Moisture & $<0.001$ & $<0.001$ & 0.262 & $<0.001$ & $<0.001$ & 0.264 & 0.147 \\
\hline Fat & $<0.001$ & $<0.001$ & 0.003 & $<0.001$ & $<0.001$ & $<0.001$ & 0.088 \\
\hline Ash & $<0.001$ & $<0.001$ & 0.052 & $<0.001$ & $<0.001$ & 0.008 & $<0.001$ \\
\hline $\mathrm{pH}$ & $<0.001$ & 0.921 & 0.962 & 0.126 & 0.299 & $<0.001$ & 0.424 \\
\hline Thawing loss & 0.279 & 0.208 & 0.054 & 0.669 & 0.109 & 0.319 & 0.222 \\
\hline Cooking loss & 0.042 & 0.012 & 0.845 & 0.067 & 0.241 & 0.755 & 0.684 \\
\hline Diameter reduction $(\mathrm{mm})$ & 0.249 & 0.565 & 0.265 & 0.318 & 0.192 & 0.705 & 0.262 \\
\hline Thickness before & 0.169 & 0.199 & 0.053 & 0.819 & 0.916 & 0.720 & 0.886 \\
\hline Thickness shrinkage after & 0.769 & 0.010 & 0.587 & 0.993 & 0.782 & 0.779 & 0.561 \\
\hline Bind strength $(\mathrm{g})$ & 0.007 & 0.229 & 0.001 & 0.065 & 0.996 & 0.943 & 0.634 \\
\hline$L^{*}$ & 0.796 & 0.630 & 0.453 & 0.999 & 0.422 & 0.852 & 0.895 \\
\hline$a^{*}$ & 0.908 & 0.106 & 0.773 & 0.754 & 0.048 & 0.516 & 0.930 \\
\hline$b^{*}$ & 0.391 & 0.825 & 0.713 & 0.439 & 0.195 & 0.346 & 0.715 \\
\hline$h$ & 0.498 & 0.477 & 0.727 & 0.499 & 0.106 & 0.326 & 0.835 \\
\hline Hardness & $<0.001$ & 0.920 & 0.709 & 0.469 & 0.219 & 0.912 & 0.747 \\
\hline Chewiness & $<0.001$ & 0.508 & 0.243 & 0.073 & 0.188 & 0.799 & 0.413 \\
\hline Cohesiveness & $<0.001$ & 0.137 & 0.654 & 0.015 & 0.219 & 0.009 & 0.004 \\
\hline Gumminess & $<0.001$ & 0.295 & 0.603 & 0.028 & 0.071 & 0.591 & 0.369 \\
\hline Springiness & 0.013 & 0.804 & 0.026 & 0.206 & 0.220 & 0.159 & 0.197 \\
\hline
\end{tabular}

Ing: ingredients; control (CP), pea protein isolate (PPI), rice protein (RP), and lentil flour (LF) (at 4 and 8\%); binding agents: Activa ${ }^{\mathrm{EB}}$ (TG) and Transgluseen$\mathrm{M}$ (TS).

retained water added to the beef steaks or as a result of the sous vide cooking technique. Moisture retention above $65 \%$ in both raw and cooked control steaks may be caused by the addition of phosphates [27]. Moisture loss after the cooking process in transglutaminase-treated samples may be caused due to the protein aggregation through glutamine lysine cross-linking $[6,14]$.

No change was perceived for fat and ash contents for raw restructured beef steaks. An analysis of variance for ash showed significant interactions $(P<0.05)$ between treatment, level, and binder for cooked samples (Table 3). Ash level was highest in cooked PPI8TS-treated steaks, due to the salt content of pea protein isolate $(3.7 \mathrm{~g} / 100 \mathrm{~g})$. In cooked LF4TS-treated steaks, fat content was highest (7.64\%), while the lowest (4.38\%) was found in control steaks.

Moreover, the protein increase observed could be associated with the rice protein at higher inclusion levels forming a denser aggregated protein network within the mixture, thus preventing fat and liquid migration from the products [28]. A similar effect was observed when Bambara groundnut seed flour was added to beef patties [29].

3.2. pH, Thawing Loss, Cooking Loss, and Dimensional Changes. An analysis of variance indicated that treatment alone and level $x$ binder had an effect $(P<0.001)$ on $\mathrm{pH}$ values (Table 2). PPI4TS, PPI8TG, and PPI8TS had higher $(P<0.01) \mathrm{pH}$ values than other treatments (Table 3$)$. The addition of nonmeat ingredients has been previously reported to increase $\mathrm{pH}$ in meat systems [30]. The interaction effect observed was not enough to reduce the performance activity of the binder used ( $\mathrm{pH}$ range: 6.01-6.12), and the ingredient levels did not have a negative impact on the restructured beef steak [5]. The optimal $\mathrm{pH}$ for catalytic activity for transglutaminase was found between $\mathrm{pH} 5$ and 8 [31]. Restructured beef steaks presented thawing losses 


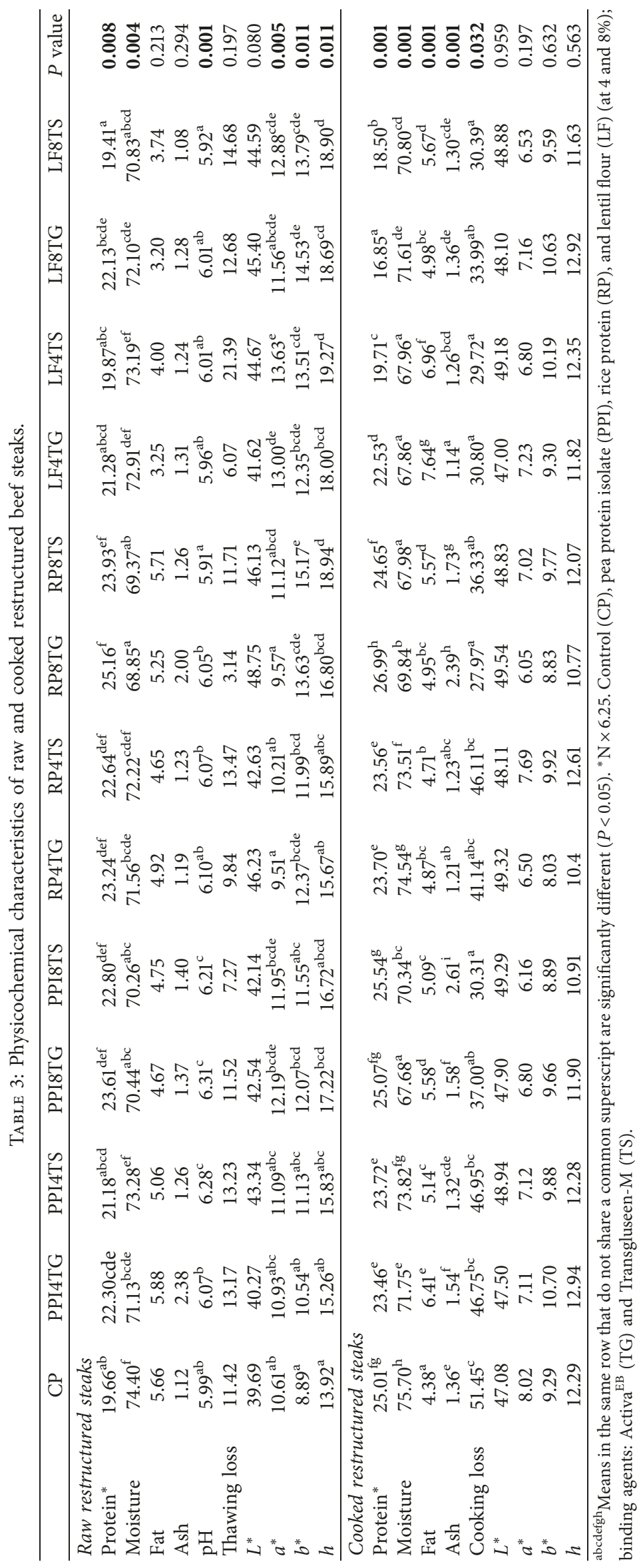




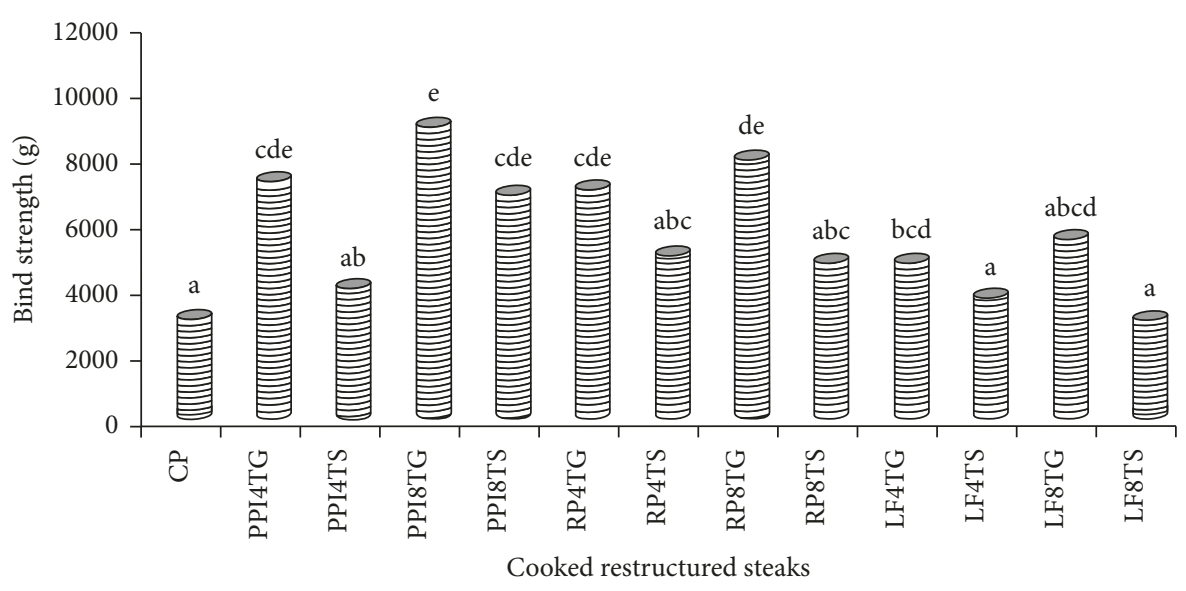

$\boxminus$ Bind strength $(\mathrm{g})$

FIGURE 1: Bind strength among protein-enriched restructured beef steaks. control (CP), pea protein isolate (PPI), rice protein (RP), and lentil flour (LF) (at 4 and 8\%); binding agents: Activa ${ }^{\mathrm{EB}}$ (TG) and Transgluseen-M (TS).

ranging from 3.14 to $21.39 \%$ (Table 3). Even though RP8TG exhibited the lowest thawing loss (3.14\%) in comparison with the control (11.42\%), these differences were not significant. Leygonie and colleagues [32] concluded that an increase in thawing time resulted in an increase in exudate release. This can be explained as the rate at which water becomes available exceeds the rate at which the meat fibres can reabsorb water resulting to increased thawing loss. The increase in thawing loss due to frozen storage had previously been reported in restructured beef steaks and ground beef $[33,34]$.

Cooking loss (CL) was significantly affected by treatment alone and level alone (Table 2). CL decreased $(P<0.05)$ with the addition of protein ingredients (Table 3 ). Irrespective of the binder used, PPI8, RP8, LF4, and LF8 had good fluid retaining abilities. This trend is supported by studies reporting improvement in cooking yield by the addition of plant protein ingredients in meat products $[5,35]$. This was most probably due to an improved protein gel formation caused by the use of proteinaceous ingredients in a meat system. This was also reported by Pietrasik et al. [36], where nonmeat proteins have been used as gelling agents in restructured or comminuted meats as they interact positively with meat proteins, increasing yield and texture by improving water holding capacities. Youssef and Barbut [37] reported that adding soy and whey protein reduced cooking losses in emulsified meat batters. This can be explained due to the loss of moisture and the dilution of meat proteins in the product as plant proteins are added [20]. It can be noted here that frozen storage did not affect cooking losses of restructured steaks in contrast to other studies [34,38]. Dimensional changes have been identified as a problem in restructured steaks including surface shrinkage (edge shrinking and curling) and interior swelling [39]; hence, the impact of the added plant proteins must, therefore, be evaluated in this instance. The diameter of all restructured steaks decreased after cooking and ranged from 34.47 to $17.14 \%$; however, this change was not affected $(P>0.05)$ by treatments, levels, or binders. Flores et al. [40] did not observe significant diameter shrinkage in pork restructured with Activa ${ }^{\mathrm{EB}}$. The thickness of all restructured beef steaks decreased after cooking. It can be concluded that ingredients and processing and storage conditions have important influences on physicochemical parameters of the product.

3.3. Binding Strength on Cooked Restructured Steaks. Bind strength for the PPI8TG sample was significantly stronger $(P<0.001)$ in comparison with the control (Figure 1). Preliminary studies indicated that a control sample with no binders and samples with Transgluseen-M without PPI, RP, and LF did not produce raw restructured steaks that would not fall apart during cooking [6]. The lowest bind strength was observed in LFTS-treated steaks. These were most similar to the control sample. Serdaroğlu et al. [4] observed similar binding properties in meatballs extended with lentil flour. This could be described by the weak emulsion formation due to the interference in the formation of a stable and uniform meat network due to the low protein and high fibre content of the flour [41]. PPI8TS-treated steaks had the closest binding strength to that of TG-treated steaks with PPI, RP, and LF. In agreement with these results, Feng and Xiong (2002) reported that soy protein may interact with meat proteins to form complexes. Analysis of variance results showed that treatment alone and binder alone had significant effects on the binding properties of the samples $(P<0.01)$ (Table 2$)$. Beef meat restructured using the commercial transglutaminase (TG) had better binding properties $(P<0.001)$ than the alternative binder (TS). This could be explained by the presence of sodium caseinate in the commercial transglutaminase used which would contribute to forming a viscous solution and act as a binding agent for restructuring meat pieces $[6,42]$. When TG was used with pea protein isolate at $8 \%$, a better gel formation was observed. These results were consistent with those obtained by Sakamoto et al. (1994), where the strength of protein gels prepared using microbial transglutaminase was enhanced in the presence of soy protein isolate and caseinate.

3.4. Colour Parameters. An overall analysis of $L^{*}, a^{*}, b^{*}$, and $h^{*}$ values for all raw treatments was influenced $(P<0.01)$ by 
the addition of plant proteins while only $b^{*}$ and $h^{*}$ were affected by the level of ingredients added $(P<0.05)$ (Table 2). Colour evaluation of $L^{*}, a^{*}, b^{*}$, and $h^{*}$ mean values for raw and cooked restructured steaks is reported in Table 3. There were no differences in $L^{*}$ values among all raw restructured steaks. The values of $a^{*}, b^{*}$, and $h^{*}$ were different $(P<0.01)$ among all raw treated steaks. RP4TS exhibited similar $(P>0.05) a^{*}$ to that of the control, whereas LF4TS demonstrated greater $(P<0.01)$ redness than the control. The observed similarity between the control and RP4TS indicated that the addition of rice protein and the alternative transglutaminase may not influence surface redness of meat products during retail display. The $b^{*}$ values of control steaks were similar to those of PPI4TG, PPI4TS, and PPI8TS, indicating that pea protein isolate at 4 and $8 \%$ in combination with TG and TS decreased yellowness. However, RP8TS exhibited greater $(P<0.01)$ $b^{*}$ values than the control. The addition of rice protein at $8 \%$ resulted in an increase in $b^{*}$, which is interpreted as an increase in $h^{*}$ angle, which can be seen in RP8TS, LF4TS, and LF8TS. Red meat colour is usually governed by myoglobin concentration, nonmeat ingredients as well as fat and water contents [43].

The brown colour in cooked meat occurs due to the denaturation of myoglobin [44]. Analysis of variance indicated that interactions of protein ingredients and binders had a reducing effect on $a^{*}$ of cooked restructured steaks (Table 2). For cooked restructured steaks, all colour parameters $\left(L^{*}, a^{*}, b^{*}\right.$, and $h^{*}$ values) presented were similar $(P>0.05)$ (Table 3$)$. These results demonstrated that cooked protein-enriched restructured steaks and control restructured steaks have similar colour and may appear similar at the point of consumption. In support of the findings in this study, Lytras et al. [45] reported no differences among treatments in their study on the addition of pea protein isolate and soy protein isolate in Turkey bologna.

In line with our results, previous studies reported raw $L^{*}$ values and cooked colour parameters were unaffected by transglutaminase levels in low-sodium caiman restructured steaks [46] and restructured pork shoulder [47].

3.5. Textural Parameters. Cooking methods as well as proximate composition (fat, moisture, protein \%) of restructured steaks have an influence on textural parameters [48]. ANOVA indicated a treatment effect among all textural parameters while an interaction effect was observed between treatment and level for cohesiveness and gumminess (Table 2). The simultaneous effect was observed when the plant proteins were added at the two different levels, which produced higher/lower cohesiveness and gumminess values. The addition of $8 \%$ rice protein in restructured beef steaks presented higher hardness values which were consistent with other studies using plantbased proteins in sausages [49] (Li et al., 1998). This increase could also be explained by the formation of glutamyl-lysyl bonds between myofibrillar proteins [46]. The use of transglutaminase in meat products strengthens the protein-protein binding, forming a rigid protein network, increasing the breaking strength, and resulting in a firmer product [50].

After cooking, LF4TS displayed lower $(P<0.001)$ values for instrumental textural parameters than the control (Figures 2(a)-2(e)). Interpretation of chewiness values was correlated to hardness values in cooked restructured beef steaks. With respect to cohesiveness, all treatments exhibited higher values except for LF4TS and LF8TG (Figure 2(e)). On the other hand, control samples and LF4TG had similar values. Tsai et al. [51] reported low cohesiveness values in restructured beef steaks with oat flour. An increase in fat content in these samples is reflected in the softer texture obtained in those restructured steaks. This response may be important in future development of meat products, which are seen as hard with a fibrous texture as reported by Baugreet et al. [5]. Another possibility is that an antagonistic interaction between meat proteins [36] and LF may cause the resulting reduced hardness in comparison with the control. This trend has been documented in previous studies (Serrano et al., 2005) [52].

3.6. Lipid Oxidation. The major cause of spoilage in restructured meat products is due to oxidative rancidity that may be accelerated by the presence of oxygen, increasing unsaturation, salts, and compositional changes due to the addition of nonmeat ingredients $[33,53]$. The extent of lipid oxidation was relatively high at day $0(1.38 \mathrm{mg} / \mathrm{MDA} / \mathrm{kg}$ of meat) in contrast to the threshold value of $1 \mathrm{mg} / \mathrm{MDA} / \mathrm{kg}$ for perceived rancidity [29]. However, this increased considerably during frozen storage for 30 days $(P<0.01,2.35 \mathrm{mg} / \mathrm{MDA} / \mathrm{kg}$ of meat). This increase could be attributed to several factors (temperature, presence of $\mathrm{O}_{2}$, cutting/chopping, processing equipment) associated with the processing of restructured beef steaks. Control beef steaks were susceptible to lipid oxidation as illustrated by higher TBA values, while PPI4TS, PP8TG, PP8TS, and RP4TG had numerically lower TBA values. However, the differences were not significant. It was previously documented that technological parameters and storage can play a detrimental role in the development of oxidation [54]. A previous study by Baugreet et al. [5] showed that the use of rice protein in beef patties effectively reduced lipid oxidation. Alternatives from natural sources such as herbs, plants, fruits, or vegetable extracts or powders could be added in future to increase the shelf life of restructured meat products. Other authors reported beneficial effects of natural antioxidants in reducing and preventing lipid oxidation $[5,55-57]$.

3.7. Microbial Analysis. All treatments exhibited 2.9-4.5 log CFU/g for psychrotrophic and 2.9-3.4 log CFU/g for LAB (data not shown). Spoilage thresholds for psychrotrophic, mesophilic, Pseudomonas, LAB, and ENT in all treatments were acceptable after 30 days of frozen storage $\left(6 \log _{10}\right.$ CFU/g) and are in accordance with Baugreet et al. [5]. This indicates that microbial safety of restructured beef steaks was not compromised by the addition of the ingredients. This is important from a commercial point of view when developing new food products for consumers. 


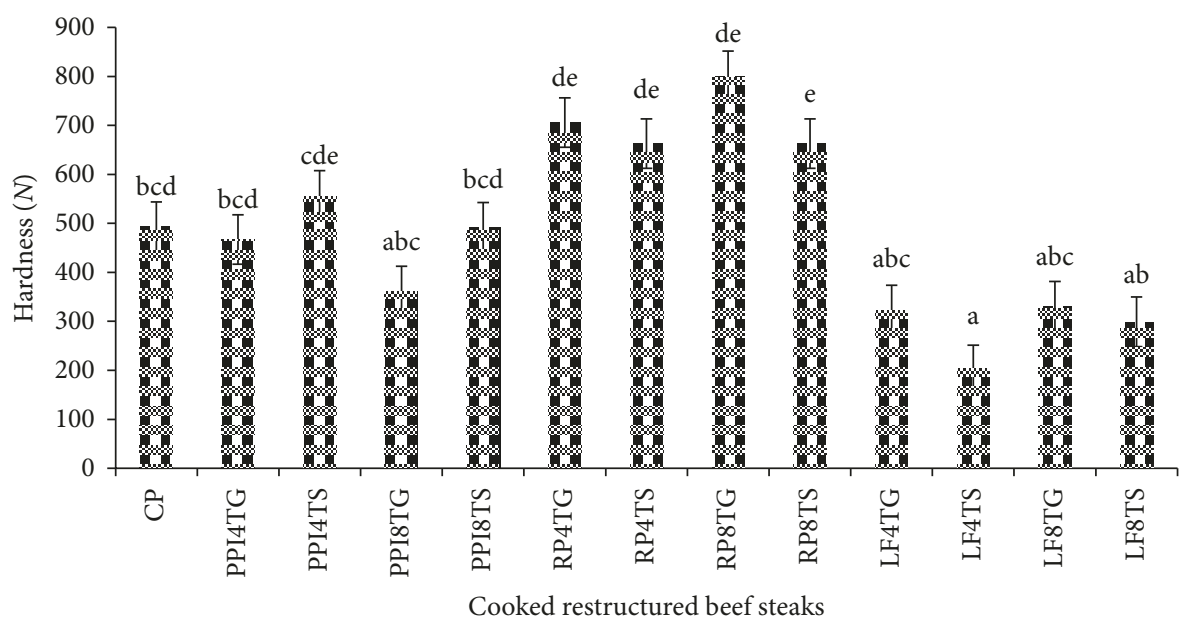

* Hardness (N)

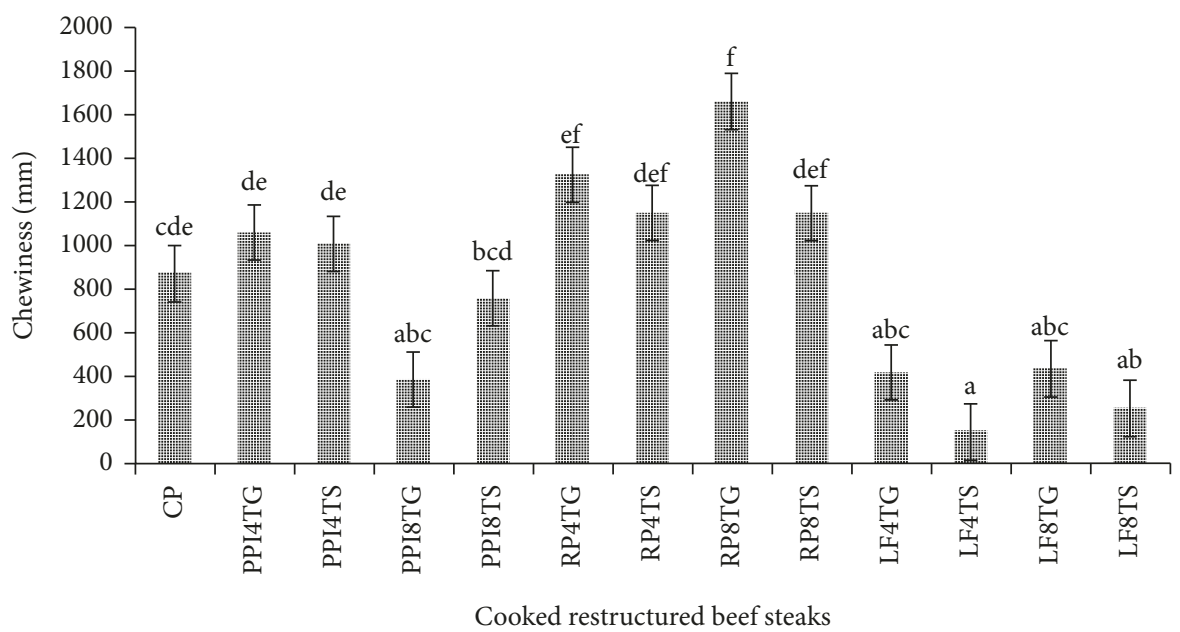

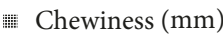

(b)

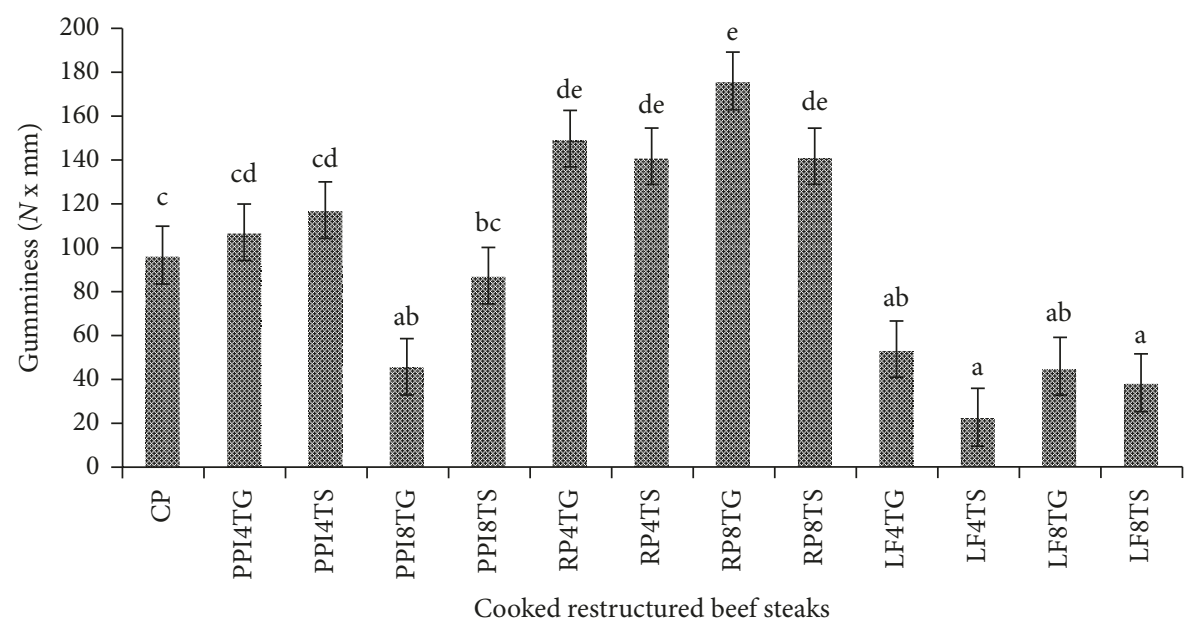

뜨․ Gumminess (N x mm)

(c)

Figure 2: Continued. 


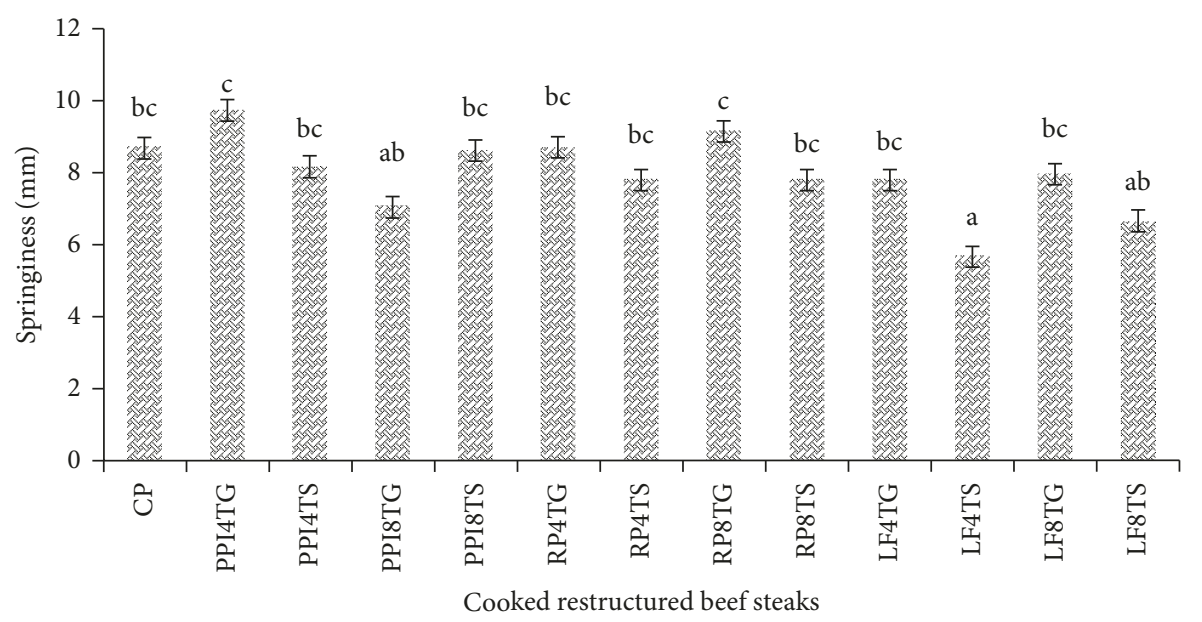

Springiness $(\mathrm{mm})$

(d)

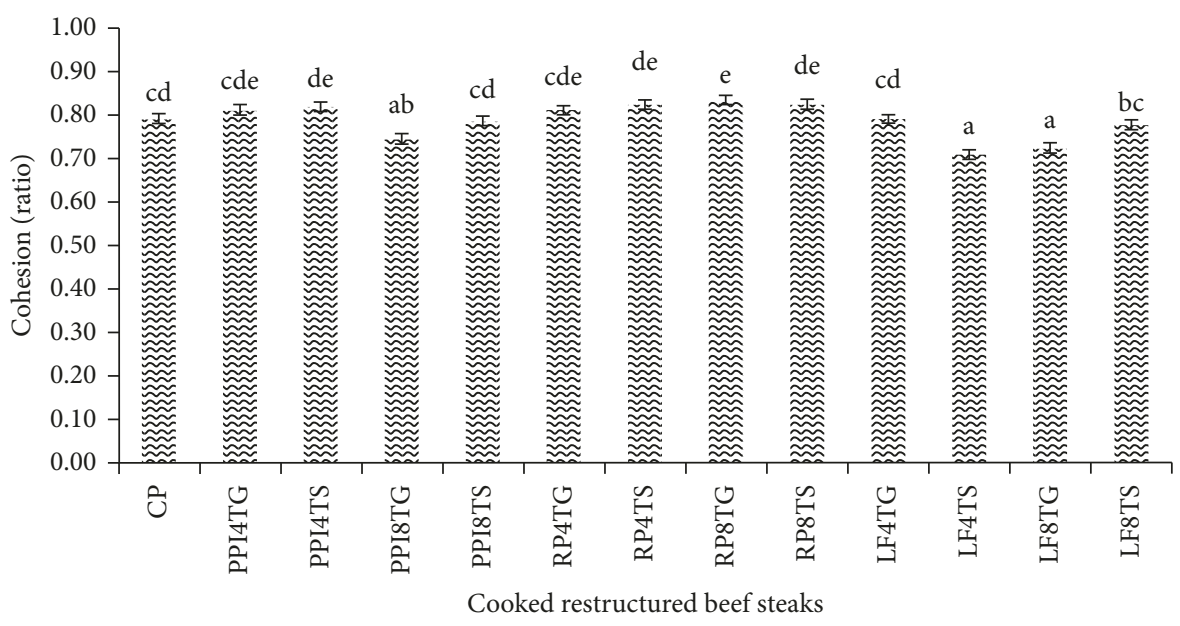

$\approx$ Cohesion (ratio)

(e)

Figure 2: Textural parameter among protein-enriched restructured beef steaks: (a) hardness, (b) chewiness, (c) gumminess, (d) springiness, and (e) cohesiveness. Control (CP), pea protein isolate (PPI), rice protein (RP), and lentil flour (LF) (at 4 and $8 \%$ ); binding agents: Activa ${ }^{\mathrm{EB}}$ (TG) and Transgluseen-M (TS).

\section{Conclusion}

This study examined the potential of plant proteins in portion controlled restructured meat products to enhance the protein content and assess the technological performance of resultant products. This wrapping technology in combination with the cold-set binder Activa $^{\mathrm{EB}}$ shows considerable potential for developing restructured beef steaks with a suitable texture for handling in the raw state. On the other hand, Transgluseen- $M$ was not as effective under the conditions used and this transglutaminase enzyme could be further optimised if it is to have applicability in meat products.

The inclusion of rice protein and pea protein isolate enhanced the protein content in restructured beef steaks; however, this increase was more pronounced with RP at $8 \%$ inclusion level. While this level was beneficial from a nutritional perspective, it also increased hardness. On the other hand, lentil-treated restructured beef steaks with TG or TS provided a softening effect on tenderness but did not increase the protein content relative to controls.

The lipid oxidation results suggested that future studies should examine natural antioxidants in combination with plant proteins to reduce lipid oxidation in restructured meat products. However, lipid oxidation is frequently associated with colour changes; here, colour degradation was not observed when plant proteins were added.

To conclude, this study demonstrates how plant proteins in conjunction with transglutaminase enzyme can be utilised in a restructured meat product to improve protein content and highlights the importance of obtaining a thorough understanding of ingredients and their interactions in processing, which may impact technological properties of resultant products. 


\section{Data Availability}

The data used to support the findings of this study are available from the corresponding author upon request.

\section{Additional Points}

(i) Restructured beef steaks formulated using plant protein ingredients (pea protein isolate, rice protein, and lentil flour) and transglutaminase enzyme (Activa ${ }^{\mathrm{EB}}$ and Transgluseen). (ii) Inclusion of rice protein and pea protein isolate enhanced the protein content in restructured beef steaks. (iii) The PiVac meat wrapping technology in combination with the cold-set binder Activa ${ }^{\mathrm{EB}}$ shows potential for developing restructured beef steaks.

\section{Conflicts of Interest}

The authors declare that they have no conflicts of interest.

\section{Acknowledgments}

The authors also wish to acknowledge the contributions of Eugene Vesey, Karen Hussey, Hans-Werner Meixer, Sarah Lynch, and Cristina Botineştean for their technical assistance. Paula Reid offered consistent help for all statistical analysis carried out. Sephora Baugreet drafted and revised all queries from reviewers in this manuscript. Paula Reid assisted in all statistical queries raised. Hans-Werner Meixer confirmed information on the PiVac technology. Ruth Hamill, Eimear Gallagher, Paul Allen, and Joseph P. Kerry provided guidance and critically revised it. This research was funded by the FIRM programme administered under the Irish Department of Agriculture, Food and the Marine, Meat4Vitality: Enhancement of texture, flavour, and nutritional value of meat products for older adults and the Walsh Fellowship Scheme (11/F/045).

\section{References}

[1] A. Mcshane, UK Consumes More Organic Meat than Any Other Country in Europe, Irish Farmers Journal, Dublin, Ireland, 2017, http://www.farmersjournal.ie/uk-consumes-more-organic-meatthan-any-other-country-in-europe-265984.

[2] A. Rutkowski and S. Gwiazda, "Functional properties of plant proteins in meat systems," Food/Nahrung, vol. 30, no. 3-4, pp. 375-381, 1986.

[3] V. K. Modi, N. S. Mahendrakar, D. Narasimha Rao, and N. M. Sachindra, "Quality of buffalo meat burger containing legume flours as binders," Meat Science, vol. 66, no. 1, pp. 143-149, 2004.

[4] M. Serdaroğlu, G. Yildiz-Turp, and K. Abrodímov, "Quality of low-fat meatballs containing legume flours as extenders," Meat Science, vol. 70, no. 1, pp. 99-105, 2005.

[5] S. Baugreet, J. P. Kerry, C. Botineştean, P. Allen, and R. M. Hamill, "Development of novel fortified beef patties with added functional protein ingredients for the elderly," Meat Science, vol. 122, pp. 40-47, 2016.

[6] Baugreet, R. Hamill, P. Allen, and J. P. Kerry, "Application of the novel PiVac technology to develop a fortified portioncontrolled restructured beef steak," Journal of Food Processing and Preservation, vol. 42, no. 2, p. e13498, 2017.
[7] A. E. D. A. Bekhit, A. Carne, M. Ha, and P. Franks, "Physical interventions to manipulate texture and tenderness of fresh meat: a review," International Journal of Food Properties, vol. 17, no. 2, pp. 433-453, 2013.

[8] O. Sørheim and K. I. Hildrum, "Muscle stretching techniques for improving meat tenderness," Trends in Food Science and Technology, vol. 13, no. 4, pp. 127-135, 2002.

[9] N. H. B. S Long, R. Gál, and F. Buňka, "Use of phosphates in meat products," African Journal of Biotechnology, vol. 10, pp. 19874-19882, 2011.

[10] X. D. Sun, "Utilization of restructuring technology in the production of meat products: a review," CyTa-Journal of Food, vol. 7, no. 2, pp. 153-162, 2009.

[11] J. Carballo, J. Ayo, and F. J. Colmenero, "Microbial transglutaminase and caseinate as cold set binders: influence of meat species and chilling storage," LWT-Food Science and Technology, vol. 39, no. 6, pp. 692-699, 2006.

[12] A. M. Ahhmed, S. Kawahara, K. Ohta, K. Nakade, T. Soeda, and M. Muguruma, "Differentiation in improvements of gel strength in chicken and beef sausages induced by transglutaminase," Meat Science, vol. 76, no. 3, pp. 455-462, 2007.

[13] E. Atilgan and B. Kilic, "Effects of microbial transglutaminase, fibrimex and alginate on physicochemical properties of cooked ground meat with reduced salt level," Journal of Food Science and Technology, vol. 54, no. 2, pp. 303-312, 2017.

[14] K. B. Chin, M. Y. Go, and Y. L. Xiong, "Konjac flour improved textural and water retention properties of transglutaminasemediated, heat-induced porcine myofibrillar protein gel: effect of salt level and transglutaminase incubation," Meat Science, vol. 81, no. 3, pp. 565-572, 2009.

[15] A. D. Dangour, V. A. Andreeva, E. Sydenham, and R. Uauy, "Omega 3 fatty acids and cognitive health in older people," British Journal of Nutrition, vol. 107, no. 2, pp. S152-S158, 2012.

[16] M. Hickson, "Malnutrition and ageing," Postgraduate Medical Journal, vol. 82, no. 963, pp. 2-8, 2006.

[17] D. E. Baldwin, "Sous vide cooking: a review," International Journal of Gastronomy and Food Science, vol. 1, no. 1, pp. 15-30, 2012.

[18] R. A. Field, J. C. Williams, V. S. Prasad, H. R. Cross, J. L. Secrist, and M. S. Brewer, "An objective measurement for evaluation of bind in restructured lamb roasts," Journal of Texture Studies, vol. 15, no. 2, pp. 173-178, 1984.

[19] N. Huda, E. Seow, M. Normawati, N. Nik Aisyah, A. Fazilah, and A. Easa, "Effect of duck feet collagen addition on physicochemical properties of surimi," International Food Research Journal, vol. 20, no. 2, pp. 537-544, 2013.

[20] F. Jiménez Colmenero, A. Serrano, J. Ayo, M. T. Solas, S. Cofrades, and J. Carballo, "Physicochemical and sensory characteristics of restructured beef steak with added walnuts," Meat Science, vol. 65, no. 4, pp. 1391-1397, 2003.

[21] M. C. Bourne, "Texture profile analysis," Food Technology, vol. 21, pp. 62-66, 1978.

[22] ISO 4833-1, "Microbiology of the food chain-horizontal method for the enumeration of microorganisms part 1 colony count at 30 degrees c by the pour plate technique," International Standards Organizations, vol. 9, 2013.

[23] ISO 17401, "Microbiology of food and animal feeding stuffshorizontal method for the enumeration of psychrotrophic microorganisms," International Standards Organization, vol. 7, 2001.

[24] ISO 13720, "Meat and meat products-enumeration of presumptive pseudomonas spp," International Standards Organizations, vol. 7, 2010.

[25] ISO 15214, "Microbiology of food and animal feeding stuffshorizontal method for the enumeration of mesophilic lactic 
acid bacteria-colony count technique at 30 degrees C, International Standards Organization, vol. 7, 1998.

[26] Regulation EU, "Commission Regulation (EU) No 432/2012 of 16 May 2012 establishing a list of permitted health claims made on foods, other than those referring to the reduction of disease risk and to children's development and health," Official Journal Of The European Union, vol. L136, pp. 1-40, 2012.

[27] E. J. Puolanne, M. H. Ruusunen, and J. I. Vainionpää, "Combined effects of $\mathrm{NaCl}$ and raw meat $\mathrm{pH}$ on waterholding in cooked sausage with and without added phosphate," Meat Science, vol. 58, no. 1, pp. 1-7, 2001.

[28] S. Baugreet, J. P. Kerry, P. Allen, and R. M. Hamill, "Optimisation of plant protein and transglutaminase content in novel beef restructured steaks for older adults by central composite design approach," Meat Science Journal, 2018, In press.

[29] J. S. Alakali, S. V. Irtwange, and M. T. Mzer, "Quality evaluation of beef patties formulated with bambara groundnut (Vigna subterranean L.) seed flour," Meat Science, vol. 85, no. 2, pp. 215-223, 2010.

[30] A. Serrano, S. Cofrades, and F. Jiménez Colmenero, "Transglutaminase as binding agent in fresh restructured beef steak with added walnuts," Food Chemistry, vol. 85, no. 3, pp. 423-429, 2004.

[31] M. Motoki and K. Seguro, "Transglutaminase and its use for food processing," Trends in Food Science and Technology, vol. 9, no. 5, pp. 204-210, 1998.

[32] C. Leygonie, T. J. Britz, and L. C. Hoffman, "Impact of freezing and thawing on the quality of meat: review," Meat Science, vol. 91, no. 2, pp. 93-98, 2012.

[33] A. Serrano, S. Cofrades, and F. Jiménez-Colmenero, "Characteristics of restructured beef steak with different proportions of walnut during frozen storage," Meat Science, vol. 72, no. 1, pp. 108-115, 2006.

[34] M. Bhattacharya, M. A. Hanna, and R. W. Mandigo, "Effect of frozen storage conditions on yields, shear strength and color of ground beef patties," Journal of Food Science, vol. 53, no. 3, pp. 696-700, 1988.

[35] Y. J. Owusu-Ansah and S. M. Mccurdy, "Pea proteins: a review of chemistry, technology of production, and utilization," Food Reviews International, vol. 7, pp. 103-134, 1991.

[36] Z. Pietrasik, A. Jarmoluk, and P. J. Shand, "Effect of non-meat proteins on hydration and textural properties of pork meat gels enhanced with microbial transglutaminase," LWT-Food Science and Technology, vol. 40, no. 5, pp. 915-920, 2007.

[37] M. K. Youssef and S. Barbut, "Effects of two types of soy protein isolates, native and preheated whey protein isolates on emulsified meat batters prepared at different protein levels," Meat Science, vol. 87, no. 1, pp. 54-60, 2011.

[38] K. W. Mcmillin, T. D. Bidner, S. E. Felchle, S. M. Dugas, and K. C. Koh, "Flavor and oxidative stability of ground beef patties as affected by source and storage," Journal of Food Science, vol. 56, no. 4, pp. 899-902, 1991.

[39] R. A. Field, "New restructured meat products-food service and retail," in Proceedings of the International Symposium on Meat Science and Technology, pp. 285-298, Lincoln, NE, USA, November 1982.

[40] N. C. Flores, E. A. E. Boyle, and C. L. Kastnerc, "Instrumental and consumer evaluation of pork restructured with Activa ${ }^{\mathrm{TM}}$ or with Fibrimex ${ }^{\mathrm{TM}}$ formulated with and without phosphate," Lwt-Food Science And Technology, vol. 40, pp. 179-185, 2007.

[41] A. K. Verma, R. Banerjee, and B. D. Sharma, "Quality characteristics of low fat chicken nuggets: effect of salt substitute blend and pea hull flour," Journal of Food Science and Technology, vol. 52, no. 4, pp. 2288-2295, 2015.
[42] R. Partanen, A. Paananen, P. Forssell et al., "Effect of transglutaminase-induced cross-linking of sodium caseinate on the properties of equilibrated interfaces and foams," Colloids and Surfaces A: Physicochemical and Engineering Aspects, vol. 344, no. 1-3, pp. 79-85, 2009.

[43] Z. Pietrasik and J. A. M. Janz, "Influence of freezing and thawing on the hydration characteristics, quality, and consumer acceptance of whole muscle beef injected with solutions of salt and phosphate," Meat Science, vol. 81, no. 3, pp. 523-532, 2009.

[44] N. J. King and R. Whyte, "Does it look cooked? A review of factors that influence cooked meat color," Journal of Food Science, vol. 71, pp. R31-R40, 2006.

[45] G. N. Lytras, A. Geileskey, R. D. King, and D. A. Ledward, "Effect of muscle type, salt and $\mathrm{pH}$ on cooked meat haemoprotein formation in lamb and beef," Meat Science, vol. 52, no. 2, pp. 189-194, 1999.

[46] A. C. V. C. S. Canto, B. R. C. C. Lima, S. P. Suman et al., "Physicochemical and sensory attributes of low-sodium restructured caiman steaks containing microbial transglutaminase and salt replacers," Meat Science, vol. 96, no. 1, pp. 623-632, 2014.

[47] M. A. Dimitrakopoulou, J. A. Ambrosiadis, F. K. Zetou, and J. G. Bloukas, "Effect of salt and transglutaminase (TG) level and processing conditions on quality characteristics of phosphate-free, cooked, restructured pork shoulder," Meat Science, vol. 70, no. 4, pp. 743-749, 2005.

[48] A. Serrano, J. Librelotto, S. Cofrades, F. J. Sanchez-Muniz, and F. Jimenez-Colmenero, "Composition and physicochemical characteristics of restructured beef steaks containing walnuts as affected by cooking method," Meat Science, vol. 77, no. 3, pp. 304-313, 2007.

[49] E. Hughes, A. M. Mullen, and D. J. Troy, "Effects of fat level, tapioca starch and whey protein on frankfurters formulated with 5\% and 12\% fat," Meat Science, vol. 48, pp. 169-180, 1998.

[50] G. A. H. Dejong and S. J. Koppelman, "Transglutaminase catalyzed reactions: impact on food applications," Journal of Food Science, vol. 67, no. 8, pp. 2798-2806, 2002.

[51] S. J. Tsai, N. Unklesbay, K. Unklesbay, and A. Clarke, "Textural properties of restructured beef products with five binders at four isothermal temperatures1," Journal of Food Quality, vol. 21, no. 5, pp. 397-410, 1998.

[52] M. Serdaroğlu, B. Öztürk, and M. Urgu, "Emulsion characteristics, chemical and textural properties of meat systems produced with double emulsions as beef fat replacers," Meat Science, vol. 117, pp. 187-195, 2016.

[53] D. A. Omana, Z. Pietrasik, and M. Betti, "Evaluation of poultry protein isolate as a food ingredient: physicochemical characteristics of low-fat turkey bologna," Poultry Science, vol. 91, no. 12, pp. 3223-3229, 2012.

[54] M.-L. Bax, L. Aubry, C. Ferreira et al., "Cooking temperature is a key determinant of in vitro meat protein digestion rate: investigation of underlying mechanisms," Journal of Agricultural and Food Chemistry, vol. 60, no. 10, pp. 2569-2576, 2012.

[55] S. Stoick, J. Gray, A. Booren, and D. Buckley, "Oxidative stability of restructured beef steaks processed with oleoresin rosemary, tertiary butylhydroquinone, and sodium tripolyphosphate," Journal of Food Science, vol. 56, no. 3, pp. 597-600, 1991.

[56] M. A. Shah, S. J. D. Bosco, and S. A. Mir, "Plant extracts as natural antioxidants in meat and meat products," Meat Science, vol. 98, no. 1, pp. 21-33, 2014.

[57] Y. Kumar, D. N. Yadav, T. Ahmad, and K. Narsaiah, "Recent trends in the use of natural antioxidants for meat and meat products," Comprehensive Reviews in Food Science and Food Safety, vol. 14, no. 6, pp. 796-812, 2015. 


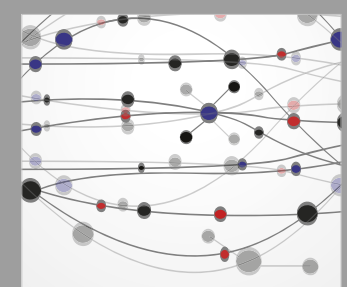

The Scientific World Journal
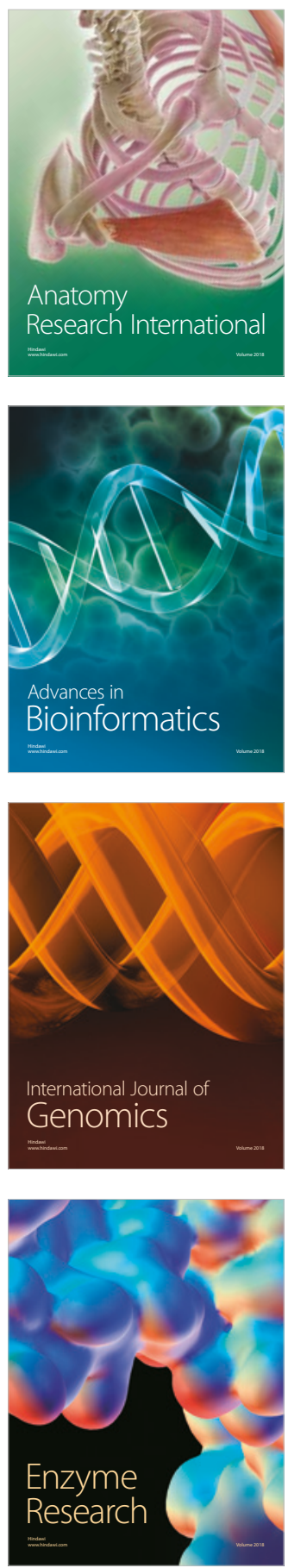
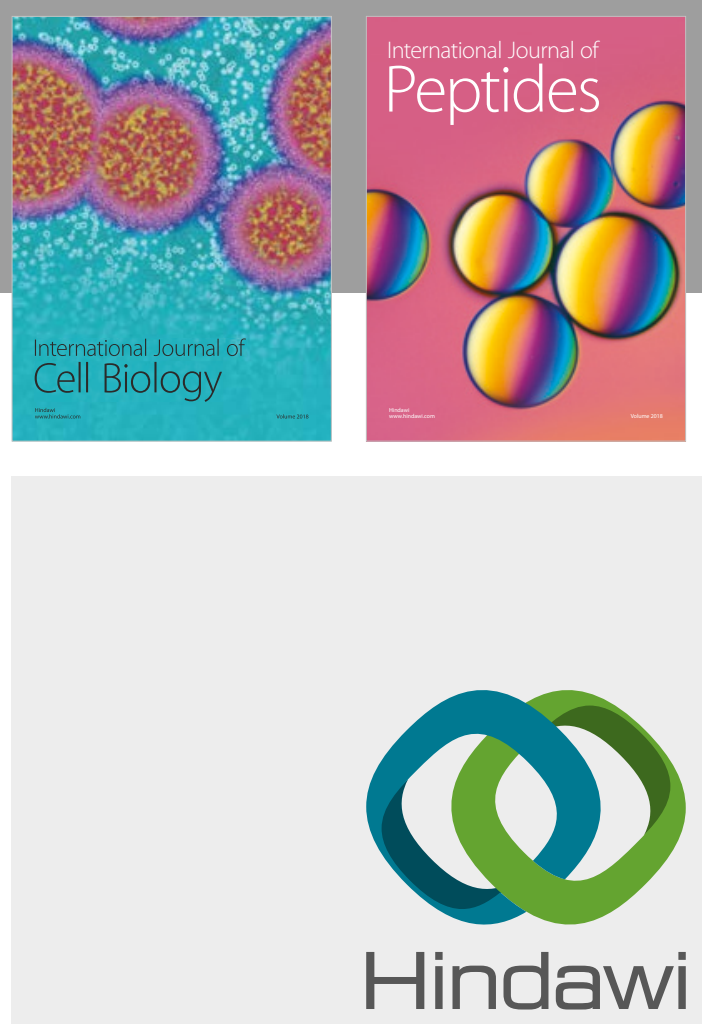

Submit your manuscripts at

www.hindawi.com
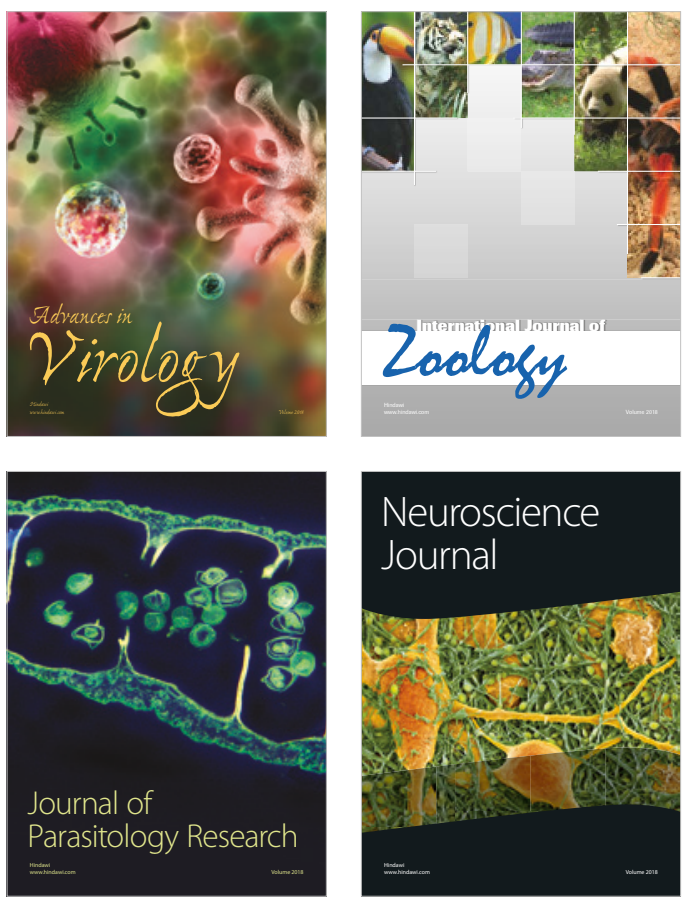
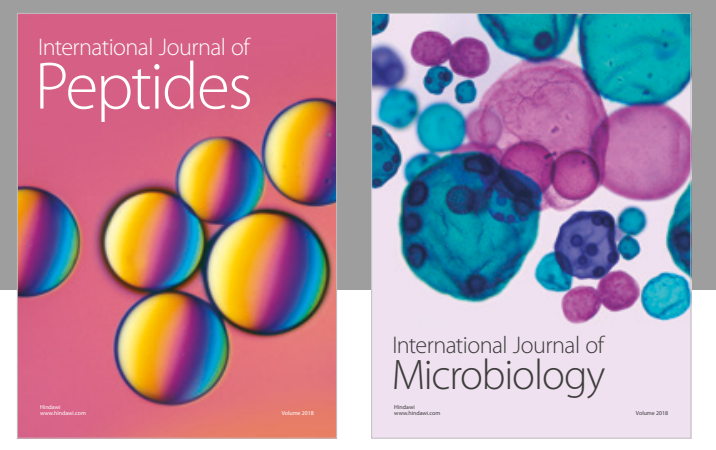

nternational Journal of Microbiology
Journal of
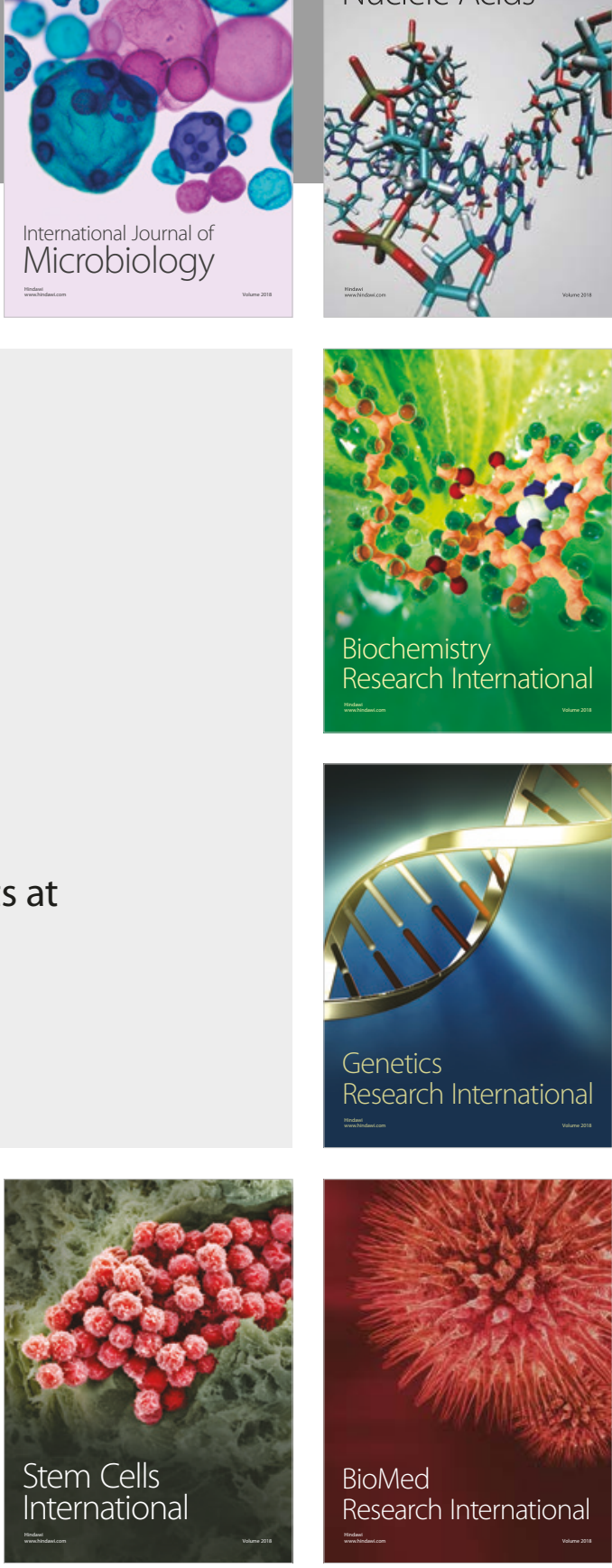
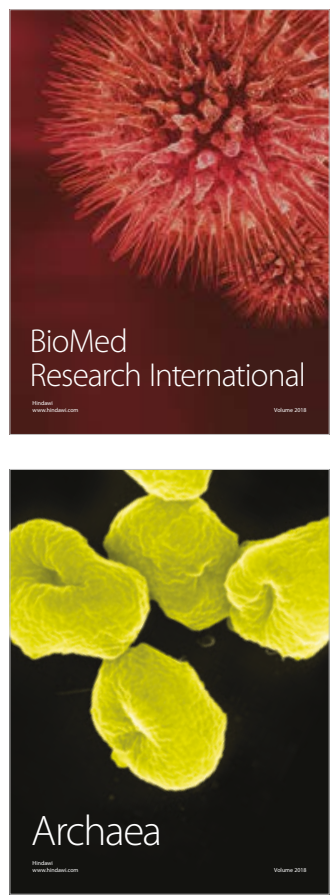